\title{
The Phonetic Basis of Perceptual Ratings of Running Speech
}




\section{Netherlands Phonetic Archives}

The Netherlands Phonetic Archives (NPA) are modestly priced series of monographs or edited volumes of papers, reporting recent advances in the field of phonetics and experimental phonology. The archives address an audience of phoneticians, phonologists and psycholinguists.

\section{Editors:}

Marcel P.R. Van den Broecke

University of Utrecht

Vincent J. van Heuven

University of Leyden

Other books in this series:

I Nico Willems

English Intonation from a Dutch Point of View

IIA A. Cohen and M.P.R. Van den Broecke (eds.)

Abstracts of the Tenth International Congress of Pbonetic Sciences

IIB M.P.R. Van den Broecke and A. Cohen (eds.)

Proceedings of the Tenth International Congress of Pbonetic Sciences

III J.R. de Pijper

Modelling British English Intonation 


\section{Lou Boves}

\section{The Phonetic Basis}

of Perceptual Ratings

of Running Speech

SYP

1984

FORIS PUBLICATIONS

Dordrecht - Holland/Cinnaminson - U.S.A. 
Publisbed by:

Foris Publications Holland

P.O. Box 509

3300 AM Dordrecht, The Netherlands

Sole distributor for the U.S.A and Canada:

Foris Publications U.S.A

P.O. Box C.50

Cinnaminson N.J. 08077

U.SA.

Boves, Lou

The Phonetic Basis of Perceptual Ratings of Running Speech / Lou Boves. - Dordrecht [etc.]: Foris Publications. - (Netherlands Phonetic Archives; 4)

ISBN $90-6765-034 \cdot \mathrm{X}$ bound

ISBN 90-6765-035-8 paper

SISO 805.2 UDC 801.4

Subject heading: speech; experimental phonetics.

Frontcover illustration taken from: F.M. Helmont [An unbreviated representation of a true natural Hebrew alphabeth, which simultaneously shows how those born deaf can be thought not only to understand others who speak but even to produce speech themselves], Pieter Roterdam, Amsterdam 1697.

\section{ISBN $906765034 \mathrm{X}$ (Bound)}

ISBN 9067650358 (Paper)

C 1984 Foris Publications - Dordrecht.

No part of this publication may be reproduced or transmitted in any form or by any means, electronic or mechanical, including photocopy, recording, or any information storage and retrieval system, without permission from the copyright owner.

Printed in the Netherlands by ICG Printing, Dordrecht. 
To the people of the Netherlands and those abroad who have contributed to our prosperity 
